\title{
Which Selective Logging Intensity is Most Suitable for the Maintenance of Soil Properties and the Promotion of Natural Regeneration in Highly Continental Scots Pine Forests?-Results 19 Years after Harvest Operations in Mongolia
}

\author{
Gerelbaatar Sukhbaatar 1,2, Baatarbileg Nachin ${ }^{2}$, Battulga Purevragchaa ${ }^{3} \mathbb{1}$, \\ Batsaikhan Ganbaatar ${ }^{3}$, Khishigjargal Mookhor ${ }^{4}$, Batchuluun Tseveen ${ }^{1,2}$ and \\ Alexander Gradel ${ }^{5,6, *}$ \\ 1 Department of Environment and Forest Engineering, School of Engineering and Applied Sciences, National \\ University of Mongolia, 14201, Mongolia; gerelbaatar@seas.num.edu.mn (G.S.); \\ batchuluun@seas.num.edu.mn (B.T.) \\ 2 Institute of Forest, National University of Mongolia, 14201, Mongolia; baatarbileg@num.edu.mn \\ 3 Division of Forest Conservation, Institute of Geography and Geoecology, Mongolian Academy of Sciences, \\ 15710, Mongolia; igg.science.secretary@gmail.com (B.P.); batlaa85@yahoo.com (B.G.) \\ 4 Department of Ecology, School of Agroecology, Mongolian University of Life Sciences, 17024, Mongolia; \\ mkhishig@muls.edu.mn \\ 5 Faculty of Forest Sciences and Forest Ecology, Universität Göttingen, Büsgenweg 5, 37077 Göttingen, \\ Germany \\ 6 International Forestry Consultancy Gradel, Bergkirchener Straße 259, 32549 Bad Oeynhausen, Germany; \\ * Correspondence: alexandergradel@yahoo.de; Tel.: +49-152-27392831
}

Received: 30 December 2018; Accepted: 4 February 2019; Published: 9 February 2019

\begin{abstract}
Scots pine (Pinus sylvestris L.) forests are one of the main vegetation types in the Asian forest-steppe zone. However, over-harvesting currently threatens the natural regeneration and sustainability of these forests. In this study, we examine the long-term effects of different logging intensities on soil properties and natural regeneration in a natural Scots pine forest in the West Khentii Mountains (Mongolia), 19 years after selective logging. Our experimental design included five treatments: clear cut (CC), treatments with high (HI), medium (MI), low (LI) intensities, and a reference parcel with no logging impact at all (RE). We described and quantified the harvest events and applied ANOVA and LMM modeling to analyze and explain the long-term impacts of the logging intensities on soil properties and natural regeneration. We found that logging has a significant negative influence on the physical and chemical properties of the soil because it increases soil compaction and reduces soil nutrients. The most critical impacts of logging were on soil bulk density, total porosity, organic matter, and total nitrogen and phosphorus. The LMM modeling showed that organic matter $(O g M)$, total nitrogen $(T N)$, available $\mathrm{K}(A K)$ and $\mathrm{pH}$ values are especially impacted by logging. Our study revealed that the values for all of these variables show a linear decrease with increasing selective logging intensity and have a level of significance of $p<0.05$. Another finding of this study is that selective logging with low and medium intensities can promote natural regeneration of Scots pine to numbers above those of the reference site (RE). High intensity logging and clear-cuts, however, limit the regeneration of Scots pine, reduce overall seedling numbers $(\mathrm{p}<0.05)$, and create conditions that are suitable only for the regeneration of deciduous tree species. This underlines the risk of Scots pine forest degradation, either by replacement by broad-leaf trees or by conversion into non-forest ecosystems.
\end{abstract}

Keywords: forestry; forest management; soil; forest steppe; regeneration; silviculture; Mongolia 


\section{Introduction}

Forests must be managed in ways that maintain their productive capacity, as well as the nutrient reserves in the soil, which facilitate the regeneration processes of the ecosystem [1]. In boreal forests, the compaction due to harvesting has significant consequences for tree regeneration [2], for the composition [3] and productivity of the forest [4,5]. Ground-based logging systems in particular can result in numerous negative consequences for the forest soil, such as decreasing water holding capacity, above ground nutrient content, availability of certain nutrients, and increasing soil compaction [1,6-9]. The physical and chemical properties and the biological interactions of the soils are of great importance for tree growth and forest reproduction $[6,10]$. Moreover, soil bulk density, porosity, and temperature reflect the soil's ability to provide structural support and to facilitate the flow of water, solutes, and air [11].

Southern boreal forests in Asia have recently warmed faster than forests in neighboring regions, and this warming pattern is projected to continue in coming decades [12]. Drier conditions are expected that affect the growth and distribution of forest and specific soil conditions, e.g. insular permafrost [13-15]. Deforestation and degradation of coniferous forests are pressing issues along the transition zone between the Siberian boreal forests and the Central Asian dry steppes. Forest succession can be difficult in this region because of the unfavorable conditions triggered by extreme temperatures and frequent aridity, and because of the sensitivity of soil and natural regeneration to climate change and unsustainable harvest practices [16-18].

Forests in Mongolia generally grow under extreme conditions, with low precipitation rates and high radiation rates prevailing throughout the year [19]. They are characterized by low productivity, poor regeneration capacity, and vulnerability to disturbance from drought, fire, and over-harvesting [17,18]. According to a World Bank study, the forestry sector plays an important role in the Mongolian economy and has great potential as a source of sustainable livelihoods for people living in forested areas [20]. However, the Government of Mongolia [18] has noted that Mongolian forests can easily lose their ecological functions after severe disturbances and are slow to recover. Different sources report that Mongolia has lost over a million ha of forests between the end of last century and 2010 due to the over-exploitation of timber and fuel wood [21,22]. This reduction differs on a regional scale. Based on the evaluation of satellite images, Teusan [23] found that in the Selenge province the total forest cover was reduced by $15 \%$ between 1990 and 2015 and that Pine forests, when compared to other forest types, had decreased particularly strongly. Other studies emphasized that land use change, such as deforestation, also has implications for the hydrological regime in Mongolia [24-26].

In northern Mongolia and neighboring regions (e.g., Tuva and Buryatia), Scots pine (Pinus sylvestris L.) is characterized by its tolerance of cold, drought, and soil infertility. It is commonly found on well drained, often sandy, soils and typically occurs in very dry forest communities in the transition zone to the steppe [27,28]. The natural distribution of Scots pine forests in Mongolia is relatively limited and largely restricted to areas with poor sandy soils. According to the recent national boreal forest inventory, Scots pine forests (defined as having a threshold value of $>75 \%$ Scots pines) constitute only about $3.1 \%$ of the total forest cover in Mongolia. As a species, Scots pine constitutes only $4.6 \%$ of the total growing stock volume, which is still equivalent to about 50.7 million $\mathrm{m}^{3}$ [29]. However, Scots pine is particularly common in the more accessible regions of Selenge, Bulgan, and Khentii provinces. Because of this and because of its wood anatomy and growth, Scots pine is a very important species for the national forest industry.

Due to increasing demand and the simultaneous decline in forest area and quality, forest management and silvicultural practices are currently challenged and discussed intensively among different stakeholders in the region. A prerequisite for being able to carry out ecological adapted utilization in the forest steppe is the sufficient regeneration of forest stands [30]. The accelerating 
trend of global warming and rapid deforestation in Mongolia emphasizes the need for appropriate timber harvesting practices. Such practices could conserve the reproductive functions of forests and reduce land degradation and deforestation at the same time. A number of studies on the effects of different logging methods of varying intensities on natural regeneration and soil properties have been carried out in different regions of the world [6,8,10,31,32]. However, there are hardly any studies of this nature for the transition zone between the boreal forests and Inner Asian steppes available. Thus, the objective of our research was to evaluate for the first time the long-term impacts of selective logging and determine the appropriate selective logging intensity for the maintenance of soil capacity and the promotion of natural regeneration in Scots pine forests in the continental Mountain forest steppe. More specifically, our goal was to study the effects of different selective logging intensities on soil properties and assess the relationship between natural regeneration and selective logging intensity 19 years after experimental logging. We hypothesized that higher selective logging intensity triggered negative long-term effects on soil properties in that way that logging i) promoted especially soil compaction, ii) decreased soil moisture, and iii) soil nutrients, and therefore iv) negatively affected natural regeneration in terms of density and species composition.

\section{Materials and Methods}

\subsection{Study Site}

Our research area is situated in the main area of distribution of Scots pine forests in Mongolia, in the West Khentii mountain range (Selenge province). We established our silvicultural experiment in an unmanaged, natural Scots pine forest that is characterized by low productivity and nutrient poor soils. These are typical features of forests in this area, where Scots pine often forms pure or almost pure stands. See Figure 1.

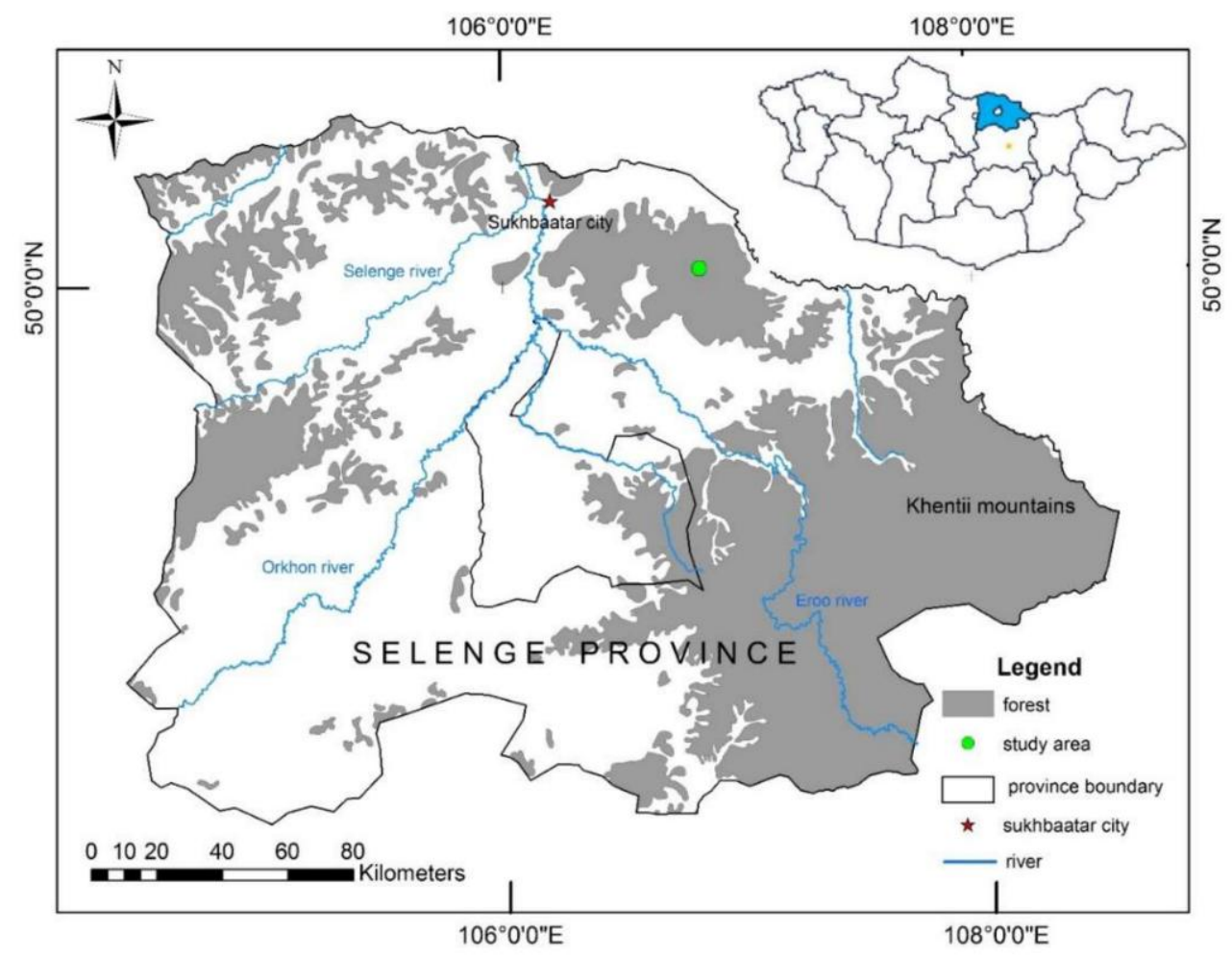

Figure 1. Location of the study area in the Selenge province.

The soils in the study area are mainly Haplic Arenosols (also called Derno-Forest soils in Mongolia), which are derived from sand sediments [33] and loess. The sandy loess stratum, which 
provides the parent materials, is extremely thick and is widely observed in the study region. We identified a brownish-black or dark brown A horizon of a few centimeters in thickness $(15-23 \mathrm{~cm}$; sandy loam) and a yellowish-brown $\mathrm{C}$ horizon in the soil profiles. The soil is characterized by relatively good water retention and is poorly vegetated. Soil texture is similar throughout the forest stand.

The elevation of the study area ranges from 650 to $750 \mathrm{~m}$ asl, with a slope of $3-15^{\circ}$ and a northern and northwestern exposition. The climate in the study area is harsh continental with a precipitation peak between June and August; more than $70 \%$ of the annual precipitation occurs during this period. The region is located within the transition climatic zone between a cool continental climate (Dwc) and a cold semi-arid climate (Bsk), with small pockets exhibiting a temperate continental climate (Dwb) (updated world map of the Köppen-Geiger climate classification; [34]). The annual average temperature is $0.31^{\circ} \mathrm{C}$ and annual precipitation is $249.3 \mathrm{~mm}$ [35]. The number of critical dry days (days with relative air humidity below 30 percent) is about 67.3 days per year.

\subsection{Treatments, Plot Design, and Data Assessment}

Criteria for the selection of the forest stand were: natural regional Scots Pine forest with relatively homogeneous structure in terms of tree species, age and tree distribution pattern, and homogenous site conditions throughout the stand. In February 1998, five different experimental logging treatments were carried out within the selected natural stand on 1-hectare treatment parcels: clear cut (CC; 100\% removal), high-intensity treatment (HI), medium-intensity treatment (MI), low-intensity treatment (LI), and no treatment at all (RE; reference, no removal). See Table 1 for basic information about the forest stand and treatments. The goals of the logging operation were to eliminate defective, suppressed, over-mature, and some mature trees to achieve sufficient distribution of the remaining trees. The cutting operations were conducted by chainsaw cutting. Trees were cut into shorter sections and carried out of the stand by manpower. All logging residuals were collected from experimental plots.

\subsubsection{Measurement of Trees before Selective Logging in Research Plots}

Three research plots measuring $20 \times 20 \mathrm{~m}(0.04$ ha; see [36,37]) were established in each treatment parcel. This made a total of fifteen research plots. Species and diameter at breast height (DBH) were noted for all trees with a minimum DBH of $6 \mathrm{~cm}$ (see Figure 2 and Table 1).

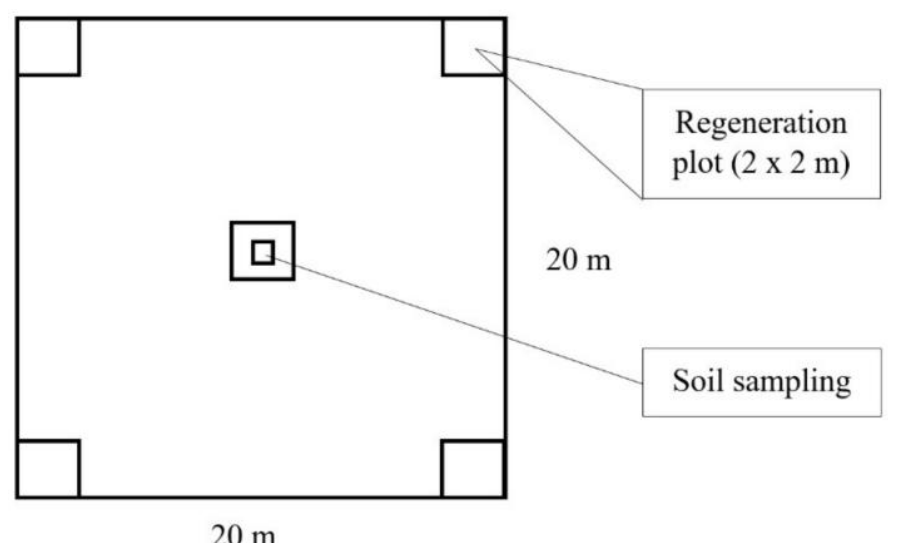

Figure 2. Design of a research plot $(20 \times 20 \mathrm{~m})$. All trees in the plot were measured. Regeneration was assessed in each of the five regeneration plots $(2 \times 2 \mathrm{~m})$. Soil sampling was carried out at the center of each research plot.

\subsubsection{Soil Sampling in Research Plots and Initial Analyses}

One soil pit was established at the center of each research plot for soil profile measurements, for a total of three soil pits per treatment parcel. Soil was sampled with a soil hammer and rings in July 2017. A total of 90 samples was taken at depths of $0-15 \mathrm{~cm}, 15-30 \mathrm{~cm}$, and $>30 \mathrm{~cm}$ for 
laboratory analyses. Soil samples were put into polyethylene bags, labeled, and brought to the laboratory. For bulk density measurements, we used a bulk density cylinder sampler (10 cm length, $5 \mathrm{~cm}$ diameter). Soil temperature and moisture were measured daily every six hours for seven days in July, starting at a depth of $5 \mathrm{~cm}$ in $10 \mathrm{~cm}$ intervals $(5,15,25,35,45,55,65 \mathrm{~cm})$. Measurements were taken with a soil Checktemp®Digital Thermometer (produced by Hanna Instruments Australia) (with an accuracy of $+/-0.1^{\circ} \mathrm{C}$ ) and a DM300L digital soil moisture meter (Shenzhen Graigar Technology Co., LTD). Calibration of the DM300L digital soil moisture meter was conducted according to Edaphic Scientific [38]. Soil samples were put into polyethylene bags, labeled, and stored in the refrigerator at $4{ }^{\circ} \mathrm{C}$ during the field survey. The collected soil samples were brought to the laboratory from the research area and promptly weighted. Soil samples were oven dried at $105{ }^{\circ} \mathrm{C}$ for $24 \mathrm{~h}$. The soil samples were sieved at $2 \mathrm{~mm}$ before wet-sieving to homogenize the samples and to remove large roots and stones. However, the gravel content was very low throughout all samples $(3.1 \%+/-0.4$ standard deviation). Therefore, 30 grams of soil were used for each soil fractionation by size, recovered from the sieves of specific screen sizes. The $\mathrm{pH}$, electrical conductivity, and chemical properties, including organic matter, total $\mathrm{N}$ and $\mathrm{P}$, and available $\mathrm{P}$ and $\mathrm{K}$ were measured at the laboratory. To measure the organic matter, the Walkley-Black method was used [39]. Kjeldahl's [40] and Olsen's method [41] were used to determine total nitrogen and phosphorus in the soil. Bray's extraction test (Bray 1 (0.03 M ammonium fluoride $\left(\mathrm{NH}_{4} \mathrm{NO}_{3}+0.025 \mathrm{M}\right.$ hydrochloric acid ( $\left.\mathrm{HCl}\right)$ extract) [42] and ammonium acetate extraction methods (neutral normal ammonium acetate $\left(1 \mathrm{~N} \mathrm{CH}_{3} \mathrm{COONH}_{4}\right)[43]$ were used to determine available phosphorus $(\mathrm{P})$ and potassium $(\mathrm{K})$, respectively. The soil $\mathrm{pH}$ and electrical conductivity were determined using a Direct Soil pH Measurement Kit (Hanna Instruments Australia) and a soil conductivity tester (soil EC tester). See Figure 2 and Table 1.

Table 1. Stand characteristics of the treatments before and after the logging operations in 1998. The growing stocks were estimated using a yield table developed by Dorjsuren et al. [44]. Stand age was derived from wood cores analyzed at the National University of Mongolia in Ulaanbaatar. RE = reference, no cutting; $\mathrm{LI}=$ low intensity; $\mathrm{MI}=$ medium intensity; $\mathrm{HI}=$ high intensity; $\mathrm{CC}=$ clear cut.

\begin{tabular}{|c|c|c|c|c|c|c|c|c|c|c|}
\hline \multirow{2}{*}{ Treatment } & \multirow{2}{*}{$\begin{array}{l}\text { Stand } \\
\text { Age in } \\
1998\end{array}$} & \multirow{2}{*}{$\begin{array}{l}\text { Number } \\
\text { of } \\
\text { Research } \\
\text { Plots }\end{array}$} & \multirow{2}{*}{$\begin{array}{l}\text { Number of } \\
\text { Regeneration } \\
\text { Plots }\end{array}$} & \multirow{2}{*}{$\begin{array}{c}\text { Number } \\
\text { of Soil } \\
\text { Pits }\end{array}$} & \multicolumn{3}{|c|}{ Stand Density (Trees ha ${ }^{-1}$ ) } & \multicolumn{3}{|c|}{$\begin{array}{l}\text { Growing Stock Volume } \\
\qquad\left(\mathrm{m}^{3} \mathrm{ha}^{-1}\right)\end{array}$} \\
\hline & & & & & $\begin{array}{c}\text { Pre- } \\
\text { Logging }\end{array}$ & $\begin{array}{l}\text { Post- } \\
\text { Logging }\end{array}$ & $\begin{array}{l}\text { Removal } \\
(\%)\end{array}$ & $\begin{array}{c}\text { Pre- } \\
\text { Logging }\end{array}$ & $\begin{array}{l}\text { Post- } \\
\text { Logging }\end{array}$ & $\begin{array}{c}\text { Removal } \\
(\%)\end{array}$ \\
\hline RE & 136 & 3 & 15 & 3 & 650 & - & - & 151.0 & - & - \\
\hline LI & 116 & 3 & 15 & 3 & 775 & 550 & 29 & 201.7 & 153.0 & 24.2 \\
\hline MI & 128 & 3 & 15 & 3 & 850 & 383 & 55 & 213.4 & 114.8 & 46.2 \\
\hline $\mathrm{HI}$ & 121 & 3 & 15 & 3 & 950 & 242 & 75 & 206.2 & 51.3 & 75.1 \\
\hline $\mathrm{CC}$ & 128 & 3 & 15 & 3 & 658 & 0 & 100 & 135.6 & 0 & 100 \\
\hline
\end{tabular}

\subsubsection{Assessment of Natural Regeneration}

We sampled natural regeneration (seedlings, saplings, and young trees $>15 \mathrm{~cm}$ in height and $<6 \mathrm{~cm}$ in DBH) in regeneration plots (five $2 \times 2 \mathrm{~m}$ regeneration plots per research plot) in July 2017 . The species of all tree seedlings and saplings in the regeneration plots were recorded. The regeneration density was calculated as the number of individuals per hectare. See Figure 2 and Table 1.

\subsection{Non-spatial Analysis of the Harvest Events in 1998}

To gain a better understanding of the character of the different treatments, we analyzed the type and intensity of the logging events [45,46] carried out in February 1998. We assessed the selective logging weight (originally referred to as the thinning weight, or "rG ratio"; [47]), which represents the intensity of the selective logging. The selective logging type was quantified with the "NG ratio" (originally denoted as thinning type; [45]). The NG ratio indicates a thinning or selective logging from below if mostly suppressed trees were removed (NG values $>1$ ), or from above if the dominant trees 
were removed (NG values $<1$ ). NG values equal to one indicate that the number of removed stems was proportional to the removed basal area $[45,48]$ :

$$
\begin{aligned}
r G & =\frac{G_{\text {removed }}\left(m^{2} / h a\right)}{G_{\text {total }}\left(m^{2} / h a\right)} \\
N G & =\frac{N_{\text {removed }} / N_{\text {total }}}{G_{\text {removed }} / G_{\text {total }}}
\end{aligned}
$$

We compared relevant stand measures and index values [46] directly before and after the harvest events in order to better quantify potential changes in diameter size classes and forest structure caused by the logging event. We analyzed the following variables: basal area $\left(\mathrm{m}^{2}\right)$, diameter coefficient of variation (CV; also denoted as DBH-differentiation [49]), quadratic mean diameter of all trees (Dg), arithmetic mean diameter of all trees (D), quadratic mean diameter of the 200 strongest trees (Dg_200), and the arithmetic mean diameter of the 200 strongest trees (D_200).

\subsection{Basic Statistical Analyses}

\subsubsection{ANOVA}

After collecting data on the soil physical and chemical properties of the different treatment sites, we carried out a one-way Analysis of Variance (ANOVA) to test whether there are significant differences in the values of physical soil properties among the different logging treatments. We used an F-test to determine equality of group means [50,51]. One-way ANOVA is relatively robust to deviations from normality, as reported by McDonald [52]. However, we additionally conducted tests for normality for each data set [53] with the following software routines: R-statistics [54] with the packages dplyr [55], ggpubr [56], car [57].

\subsubsection{Correlation between Selective Logging Intensity and Soil Property Variables}

For a first overview, we used Pearson's correlation coefficient [58] to explore the relationships between logging intensities and soil property variables. Values were expressed as the mean \pm standard error of the mean.

We used Excel 2016 (Microsoft Corp.) and R-statistics [54] for the basic statistical analyses.

2.5. Quantification of the Impact of Selective Logging Intensity on Soil Properties and Regeneration with Linear Mixed Models (LMM)

After the basic statistical analyses, we developed and tested explanatory models for the following soil property variables based on our indicator for selective logging intensity rG (selective logging weight): $\mathrm{pH}$ value $(p H)$, organic matter $(O g M)$, total $\mathrm{N}(T N)$, total $\mathrm{P}(T P)$, available $\mathrm{P}(A P)$, and available potassium $(A K)$. We used the same approach to develop explanatory models to derive regeneration numbers for pine (Rpine) and for all tree species (Rall_species). Advantages of the LMM approach are that pseudo-replication is avoided and that it includes fixed effects (such as $\mathrm{rG}$ ) and random effects (e.g., site and plot) [59-61]. The models were optimized based on the restricted maximum likelihood method (REML) [60,61]. We evaluated every initial model run using standard regression diagnostics in which outliers were detected and eliminated based on the distribution of internally studentized residuals in Q-Qplots with a 95\% confidence envelope [62]. The best models were selected according to the following criteria: Akaike's information criterion (AIC), Bayesian information criterion (BIC), the value of the log likelihood, the plausibility of the intercept, the distribution of residuals, and the plausibility of the respective model from an ecological point of view [46]. The mean values of soil property variables or the mean regeneration numbers of the sample $i$ of a research plot $j$ represent one 
sample unit. Regeneration numbers always refer to one hectare. The general mathematical description for explaining the values of the soil property variables is:

$$
\text { soil_var }_{i j}=\left(\beta_{0}\right) \text { Intercept }+\left(\beta_{1, \mathrm{i}}\right) r G+\left(b_{2, j}\right) \text { plot }+\varepsilon_{i j}
$$

where soil_var refers to the above-mentioned soil property variables ( $p H, O g M, T N, T P, A P$ or $A K), \beta_{0}$, $\beta_{1}$, and $b_{2, j}$ are the parameter estimates of the intercept, of the fixed effect $(\mathrm{rG})$ and the research plot, and $\varepsilon_{i j}$ is the error term of the soil sample $i$ in research plot $j$.

The general mathematical description of the regeneration model is:

$$
R_{i j}=\left(\beta_{0}\right) \text { Intercept }+\left(\beta_{1, \mathrm{i}}\right) r G+\left(b_{2, \mathrm{j}}\right) \text { plot }+\varepsilon_{i j}
$$

where $R$ refers to the regeneration of pine (Rpine) or the regeneration of all tree species (Rspecies), $\beta_{0}$, $\beta_{1}$, and $b_{2, j}$ are the parameter estimates of the intercept, of the fixed effect $(\mathrm{rG})$ and the research plot, respectively, and $\varepsilon_{i j}$ is the error term of the regeneration $i$ in research plot $j$.

The following software packages/routines were used: R-statistics [54] with the packages nls2 [63], nlme [64], car [57], and lattice [65].

\section{Results}

\subsection{Non-Spatial Harvest Event Analysis of the Harvest Operation in 1998}

We compared the selective logging weights and the selective logging types of the different treatments. As expected, logging weight $(\mathrm{rG})$ varied from low (low intensity treatment, LI with $\mathrm{rG}=0.24$ ) to very heavy (high intensity treatment, $\mathrm{HI}$ with $\mathrm{rG}=0.74 ; \mathrm{CC}$ with $\mathrm{rG}=1.00$ ). The logging type (NG) values of all treatments were around 1 , which indicated a rather even selection of larger and smaller trees on the plots. The NG ratio of 1.10 (at LI) indicates a slight tendency towards logging from below (more frequent removal of relatively smaller trees; see Figure 3). The diameter coefficient of variation $(\mathrm{CV})$ was low to medium before the harvest and decreased slightly following the logging operations. Arithmetic mean diameter (D) and quadratic mean diameter (Dg) did not change much. However, the respective values of the 200 strongest trees per hectare, D_200 and Dg_200 changed and became weaker, especially following the MI and HI treatments (see Figure 3 and Table 2).

Table 2. Stand measures and index values of the plots before (pre-logging) and after the harvest operations (post-logging) in 1998. BA/ha=basal area $\left(\mathrm{m}^{2}\right)$ per hectare; CV: diameter coefficient of variation; D: arithmetic mean diameter of all measured trees; Dg: quadratic mean diameter of all measured trees: Dg_200: quadratic mean diameter of the 200 strongest trees per ha; D_200: arithmetic mean diameter of the 200 strongest trees per ha. $\mathrm{RE}=$ reference, no cutting; $\mathrm{LI}=$ low intensity; $\mathrm{MI}=$

\begin{tabular}{|c|c|c|c|c|c|c|c|c|c|c|c|c|}
\hline \multirow[b]{2}{*}{ Treatment } & \multicolumn{2}{|c|}{ BA/ha } & \multicolumn{2}{|c|}{$\mathrm{CV}$} & \multicolumn{2}{|c|}{$D(\mathrm{~cm})$} & \multicolumn{2}{|c|}{$\mathrm{Dg}(\mathrm{cm})$} & \multicolumn{2}{|c|}{ D_200 (cm) } & \multicolumn{2}{|c|}{$\mathrm{Dg} \_200(\mathrm{~cm})$} \\
\hline & $\begin{array}{c}\text { Pre- } \\
\text { Logging }\end{array}$ & $\begin{array}{l}\text { Post- } \\
\text { Logging }\end{array}$ & $\begin{array}{c}\text { Pre- } \\
\text { Logging }\end{array}$ & $\begin{array}{c}\text { Post- } \\
\text { Logging }\end{array}$ & $\begin{array}{c}\text { Pre- } \\
\text { Logging }\end{array}$ & $\begin{array}{c}\text { Post- } \\
\text { Logging }\end{array}$ & $\begin{array}{c}\text { Pre- } \\
\text { Logging }\end{array}$ & $\begin{array}{c}\text { Post- } \\
\text { Logging }\end{array}$ & $\begin{array}{c}\text { Pre- } \\
\text { Logging }\end{array}$ & $\begin{array}{l}\text { Post- } \\
\text { Logging }\end{array}$ & $\begin{array}{c}\text { Pre- } \\
\text { Logging }\end{array}$ & $\begin{array}{c}\text { Post- } \\
\text { Logging }\end{array}$ \\
\hline RE & 21.880 & 21.880 & 0.306 & 0.306 & 19.8 & 19.8 & 20.7 & 20.7 & 26.6 & 26.6 & 26.8 & 26.8 \\
\hline LI & 28.993 & 21.972 & 0.348 & 0.318 & 20.7 & 21.5 & 21.9 & 22.6 & 29.9 & 28.4 & 30.1 & 28.7 \\
\hline MI & 30.395 & 14.798 & 0.361 & 0.249 & 20.2 & 21.5 & 21.4 & 22.2 & 29.6 & 25.4 & 29.9 & 25.6 \\
\hline HI & 29.874 & 7.635 & 0.371 & 0.227 & 18.7 & 19.6 & 20.0 & 20.1 & 28.3 & 19.1 & 28.4 & 19.7 \\
\hline $\mathrm{CC}$ & 19.991 & - & 0.343 & - & 18.6 & - & 16.3 & - & 29.9 & - & 26.1 & - \\
\hline
\end{tabular}
medium intensity; $\mathrm{HI}=$ high intensity; $\mathrm{CC}$ = clear cut. 


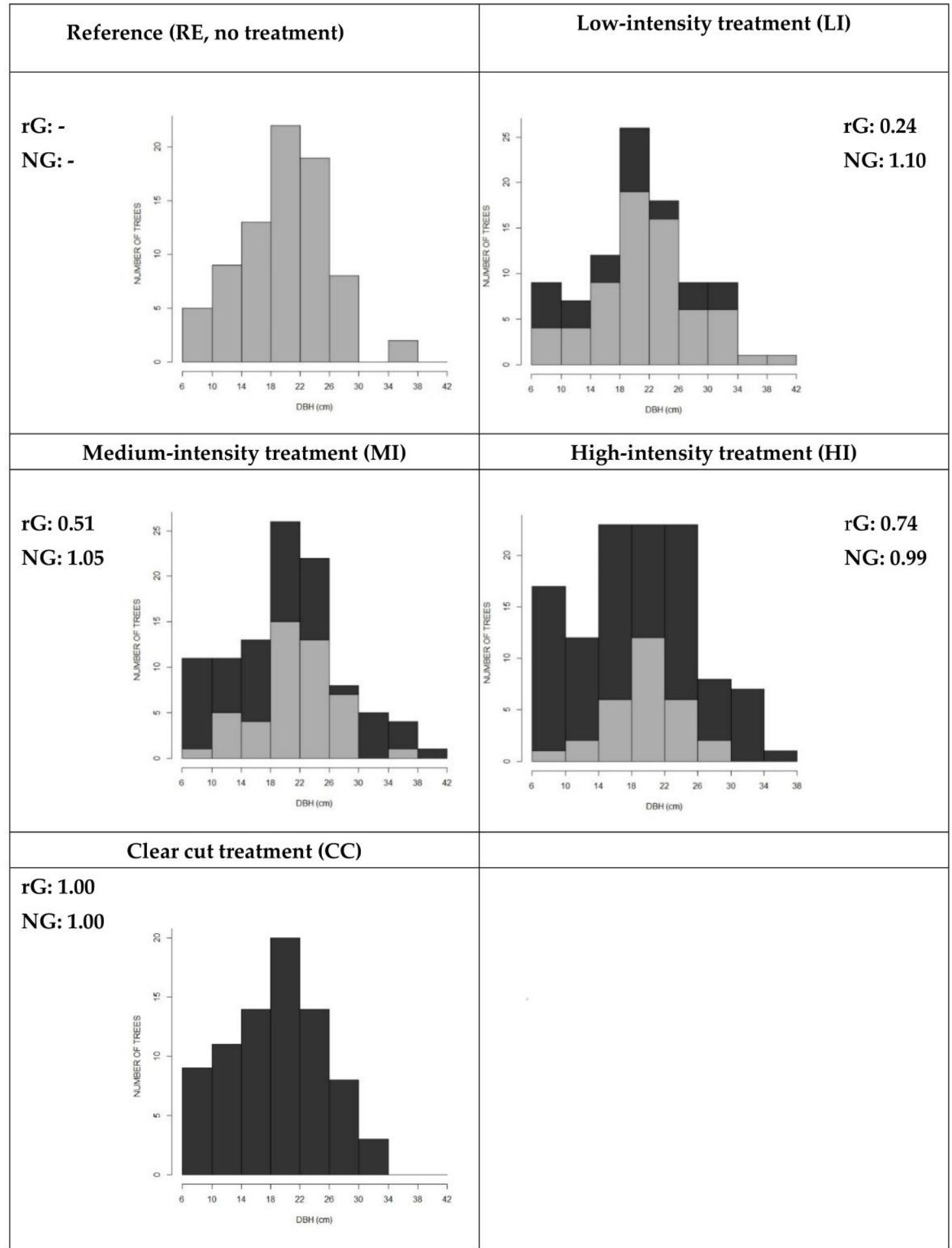

Figure 3. Characterization of the different selective logging treatments in 1998; grey: trees remaining after logging; black: trees removed during logging; $r G$ = selective logging weight (logging intensity); $\mathrm{NG}=$ selective logging type.

\subsection{Impact of Logging Intensities on Physical Soil Properties in 2017}

Overall, soil bulk density $(\mathrm{r}=0.92)$, total soil porosity $(\mathrm{r}=-0.91)$, temperature $(\mathrm{r}=0.87)$, and moisture content $(\mathrm{r}=-0.83)$ of the soil were highly correlated with logging intensity. Results of the assessment revealed that soil bulk density and temperature tended to increase with increasing logging intensity, whereas soil porosity and moisture content declined. 
Regarding the components of topsoil exposed to different selective logging intensity, soil porosity values were often lower at the MI (39\%), HI (38\%), and CC (31\%) treatment parcels compared to the RE parcel (44\%), whereas soil bulk density values were greater at the MI $\left(1.38 \mathrm{~g} \mathrm{~cm}^{-3}\right), \mathrm{HI}\left(1.42 \mathrm{~g} \mathrm{~cm}^{-3}\right)$, and CC $\left(1.57 \mathrm{~g} \mathrm{~cm}^{-3}\right)$ parcels compared to the reference stand $\left(1.28 \mathrm{~g} \mathrm{~cm}^{-3}\right.$; Figure 4$)$. We found that harvesting with low and medium intensity did not significantly change the physical properties of topsoil and subsoils. There was a significant $(p<0.001)$ difference in soil bulk density depending on soil depth. The 15-30 cm depth interval had higher soil bulk density than the $0-15 \mathrm{~cm}$ interval. Likewise, there was a significant difference in soil bulk density among treatments, with HI and CC treatments having a higher soil bulk density than RE and LI treatments. Relative to RE, soil bulk density at $0-15 \mathrm{~cm}$ depth increased $10.9 \%$ for $\mathrm{HI}$ and $22.6 \%$ for CC. At the $15-30 \mathrm{~cm}$ depth, the increase in soil bulk density was $9.8 \%$ and $23.4 \%$ for $\mathrm{HI}$ and CC, respectively. There was no significant $(p<0.05)$ difference in soil porosity between soil depths, although the $0-15 \mathrm{~cm}$ depth had a higher soil porosity than the $15-30 \mathrm{~cm}$ depth. However, we found a significant $(\mathrm{F}=5,65, p<0.001)$ difference in soil porosity between different treatment parcels. At the HI and CC sites, where heavy logging had been carried out, soil porosity was less than at the RE, LI, and MI treatment parcels. Total porosity at $0-15 \mathrm{~cm}$ depth decreased by $29.5 \%$; at $15-30 \mathrm{~cm}$ depth, it decreased by $21.6 \%$.

Temperature in the upper $10 \mathrm{~cm}$ was especially high in $\mathrm{HI}$ and CC parcels, whereas soil moisture, especially in the upper horizon, was lowest in CC and HI parcels and highest in RE (Figure 4, Figure 5). Significant differences were found in soil moisture $(F=107,9, p<0.001)$ and temperature $(F=19.09$, $p=0.009)$ throughout the soil profiles between treatments. The highest temperature values and lowest moisture content values were recorded in topsoil at $\mathrm{HI}\left(28.9{ }^{\circ} \mathrm{C}, 8.33 \%\right)$ and $\mathrm{CC}\left(29.4{ }^{\circ} \mathrm{C}, 5,67 \%\right)$ treatment parcels.

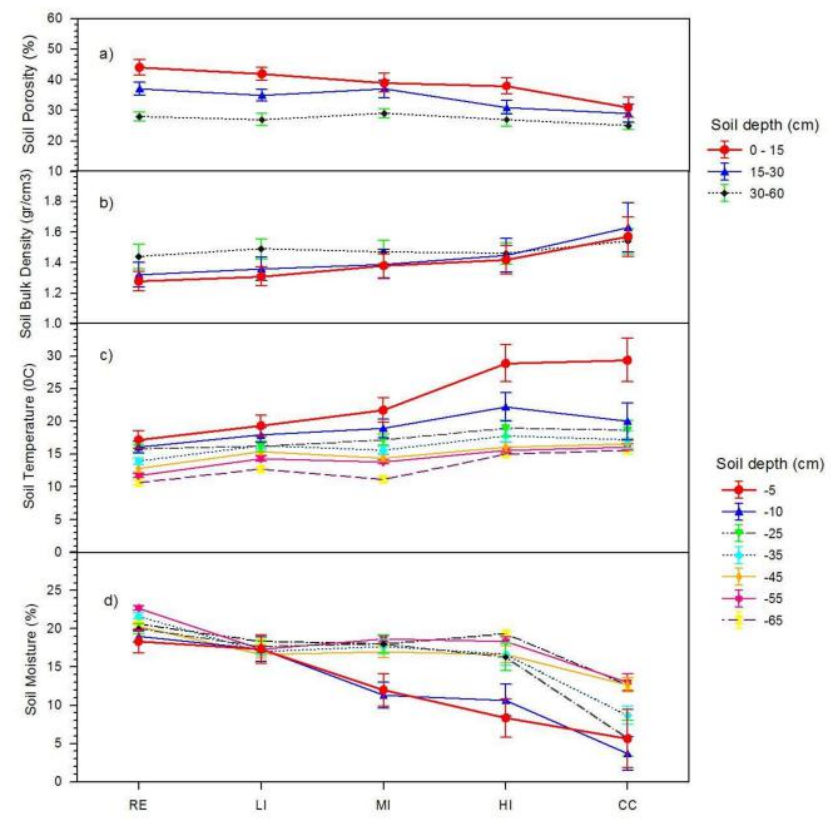

Figure 4. Comparison of soil porosity, soil bulk density, soil temperature, and moisture at different depths in the soil profiles. 


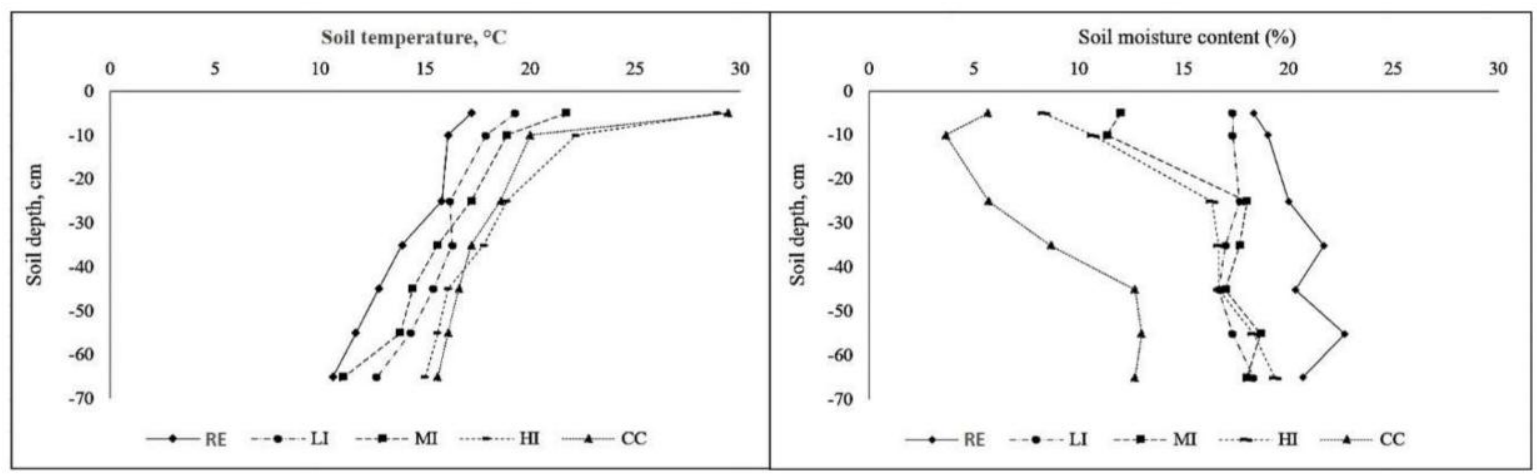

Figure 5. Soil temperature and moisture at different depths in the soil profiles.

\subsection{Impact of Selective Logging Intensities on Chemical Soil Properties in 2017}

Results of the assessment showed a clear deterioration of soil chemical properties with an increase in harvest intensity. Nineteen years after the logging, soil nutrient contents were highest under reference conditions and low selective logging intensity (RE and LI treatment parcels). Higher selective logging intensity (i.e., at HI and CC treatment parcels) triggered the loss of nutrient content. Noticeable negative effects of logging on soil chemical properties were observed under high intensity logging (HI) and clear-cutting treatments (CC), where organic matter content, total $\mathrm{N}$, total $\mathrm{P}$, and available $\mathrm{K}$ decreased strongly compared to the reference level (RE). These variables showed the highest negative correlations, ranging between -0.86 and -0.91 (with $p<0.05$ ). Moreover, the results indicated that intensive logging lead to lower total $\mathrm{P}$ and lower $\mathrm{pH}$ values, and consequently soil acidification. See Table 3 for the specific average values per treatment.

Table 3. Means and standard deviations of soil chemical properties 19 years after cutting.

\begin{tabular}{|c|c|c|c|c|c|c|c|}
\hline Treatment & $\begin{array}{c}\mathrm{EC}(\mathrm{dS} \\
\left.\mathrm{m}^{-1}\right)\end{array}$ & $\mathrm{pH}$ & $\begin{array}{c}\text { Organic } \\
\text { Matter (\%) }\end{array}$ & $\begin{array}{c}\text { Total } \\
\text { Nitrogen }(\mathrm{N}) \\
\left(\mathrm{g} \mathrm{kg}^{-1}\right)\end{array}$ & $\begin{array}{c}\text { Total } \\
\text { Phosphorus } \\
(P)\left(\mathrm{g} \mathrm{kg}^{-1}\right)\end{array}$ & $\begin{array}{c}\text { Available } \\
\text { Phosphorus } \\
\text { (P) }\left(\mathrm{mg} \mathrm{kg}^{-1}\right)\end{array}$ & $\begin{array}{c}\text { Available } \\
\text { Potassium (K) } \\
\left(\mathrm{mg} \mathrm{kg}^{-1}\right)\end{array}$ \\
\hline RE & 0.12 & $6.75(0.05)$ & $19.7(1.0)$ & $0.93(0.03)$ & $0.091(0.003)$ & $3.45(0.04)$ & $18.35(2.4)$ \\
\hline LI & 0.14 & $6.66(0.03)$ & $19.3(0.8)$ & $0.91(0.09)$ & $0.093(0.007)$ & $2.43(0.02)$ & $19.56(3.6)$ \\
\hline MI & 0.11 & $6.71(0.04)$ & $17.5(1.2)$ & $0.80(0.05)$ & $0.087(0.005)$ & $1.13(0.07)$ & $16.32(2.7)$ \\
\hline $\mathrm{HI}$ & 0.09 & $6.58(0.05)$ & $15.2(0.9)$ & $0.72(0.10)$ & $0.086(0.002)$ & $2.56(0.06)$ & $10.45(3.3)$ \\
\hline $\mathrm{CC}$ & 0.08 & $6.52(0.03)$ & $11.5(0.7)$ & $0.61(0.02)$ & $0.082(0.005)$ & $2.92(0.04)$ & $8.74(1.9)$ \\
\hline
\end{tabular}

${ }^{*}$ Results are means \pm standard error in brackets.

\subsection{Regeneration Density and Species Composition}

The correlation between treatments and overall regeneration number was low when the RE-parcel was included $(\mathrm{r}=-0.398 ; p$-value $=0.141)$. However, when considering only treatments with removal (LI, MI, HI and CC) the regeneration number highly correlated negatively with selective logging intensity $(\mathrm{r}=-0.9 ; p$-value $<0.001)$. The highest regeneration densities were observed in LI parcels (3333 stems ha ${ }^{-1}$ ), followed by MI parcels (2167 stems ha ${ }^{-1}$ ) (Figure 6). RE and HI parcels had relatively low regeneration densities but differed in composition. At RE, LI, and MI parcels, we found only Scots pine seedlings and no other tree species. At HI sites, we found low density Scots pine regeneration, but also poplar and birch regeneration. The poorest regeneration densities were observed at CC and RE parcels. The regeneration at CC parcels consisted of only single birches and willows. 


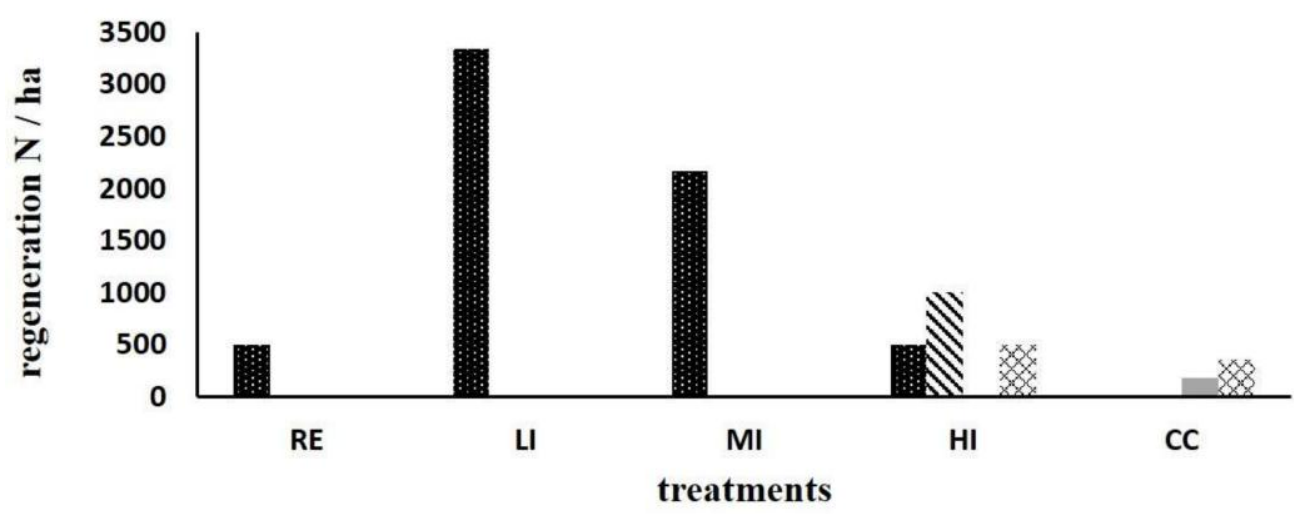

Pinus sylvestris $\aleph$ Populus tremula $₫$ Salix pentandra $₫$ Betula platyphylla

Figure 6. Assessed regeneration density (height $>15 \mathrm{~cm}$ and diameter at breast height (DBH) $<6 \mathrm{~cm}$; $\mathrm{N} /$ ha) of the different treatments in 2017 . When considering only treatments with removal (LI-CC) the trend is almost linear negative.

3.5. Differences in Soil Properties and Regeneration Explained by Different Selective Logging Intensities via Linear Mixed Effect Models

The elaborated models for soil property variables (Formula 3a) and regeneration (Formula 3b) confirmed that increasing selective logging intensity has mostly significant negative impacts on the respective variables. The $p$-values of the fixed effect $(\mathrm{rG})$ indicated that regeneration of Scots pine and of all tree species decreased significantly $(p<0.05)$ with increasing logging impact. However, the slope of the linear regression was steeper for Scots pine (Rpine) than for all tree species (Rspecies). We obtained similar results for $\mathrm{pH}$, organic matter content $(O g M)$, total nitrogen $(T N)$, and available potassium $(A K)$, all of which decreased significantly with increasing logging impact. Only the $p$-values for phosphorus were not significant at the level of $p<0.05$, although we obtained significant results for total phosphorus at the level of $p<0.10$. Based on the QQ-plots we had to conduct outlier corrections for two models (variables Rpine and AP; see Table 4 and Figure 7).

Table 4. Overview of the elaborated linear mixed effect models (LMM). The models for explaining soil property variables (a) were elaborated for $\mathrm{pH}=$ average $\mathrm{pH}$ values, $\mathrm{OgM}=$ average organic matter content $(\%), \mathrm{TN}=$ total $\mathrm{N}$ (nitrogen; $\mathrm{g} \mathrm{kg}^{-1}$ ), $\mathrm{TP}=$ total $\mathrm{P}$ (phosphorus; $\mathrm{g} \mathrm{kg}^{-1}$ ), $\mathrm{AP}=$ available $\mathrm{P}$ (phosphorus $\mathrm{mg} \mathrm{kg}^{-1}$ ), and $\mathrm{AK}=$ available $\mathrm{K}$ (potassium; $\mathrm{mg} \mathrm{kg}^{-1}$ ); with $\mathrm{rG}$ (selective logging weight) between 0.0 and 1.0. The models for explaining regeneration $(\mathrm{b})$ were elaborated for Rpine= average regeneration density of Scots pine $(\mathrm{N} / \mathrm{ha})$, and Rspecies = average regeneration density of all tree species (N/ha); with rG (logging weight) between 0.2 and 1.0. AIC = Akaike's Information Criterion.

\begin{tabular}{|c|c|c|c|c|c|c|c|c|c|c|}
\hline \multirow{2}{*}{$\begin{array}{c}\text { Thematic } \\
\text { Topic }\end{array}$} & \multirow{2}{*}{ Model } & \multirow{2}{*}{ Variable } & \multirow{2}{*}{$\begin{array}{l}\text { Fixed } \\
\text { Effects }\end{array}$} & \multirow{2}{*}{$\begin{array}{c}\text { Degrees } \\
\text { of } \\
\text { Freedom }\end{array}$} & \multirow{2}{*}{$\begin{array}{c}\text { Outlier } \\
\text { Correction }\end{array}$} & \multicolumn{4}{|c|}{ Model Parameter (Fixed Effects) } & \multirow{2}{*}{$\begin{array}{l}\text { AIC of the } \\
\text { Model }\end{array}$} \\
\hline & & & & & & Intercept & $p$-Value & rG & $p$-Value & \\
\hline \multirow{6}{*}{$\begin{array}{c}\text { (a) soil } \\
\text { property } \\
\text { variables }\end{array}$} & (a)1 & $\mathrm{pH}$ & $\mathrm{rG}$ & 13 & no & 6.738 & 0.0000 & -0.198 & 0.0304 & -8.75 \\
\hline & (a) 2 & $\mathrm{OgM}$ & $\mathrm{rG}$ & 13 & no & 20.772 & 0.0000 & -8.229 & 0.0000 & 57.48 \\
\hline & (a) 3 & $\mathrm{TN}$ & $\mathrm{rG}$ & 13 & no & 0.959 & 0.0000 & -0.332 & 0.0000 & -18.87 \\
\hline & (a) 4 & $\mathrm{TP}$ & $\mathrm{rG}$ & 13 & no & 0.093 & 0.0000 & -0.010 & 0.0760 & -80.22 \\
\hline & (a) 5 & $\mathrm{AP}$ & $\mathrm{rG}$ & 11 & yes $(-2)$ & 2.888 & 0.0000 & -0.376 & 0.4639 & 33.86 \\
\hline & (a) 6 & AK & $\mathrm{rG}$ & 13 & no & 20.321 & 0.0000 & -11.316 & 0.0000 & 68.84 \\
\hline (b) & (b)1 & Rpine & $\mathrm{rG}$ & 9 & yes $(-1)$ & 4125 & 0.0000 & -4436 & 0.0000 & 147.91 \\
\hline regeneration & (b) 2 & Rspecies & $\mathrm{rG}$ & 10 & no & 4141 & 0.0000 & -3630 & 0.0000 & 166.17 \\
\hline
\end{tabular}




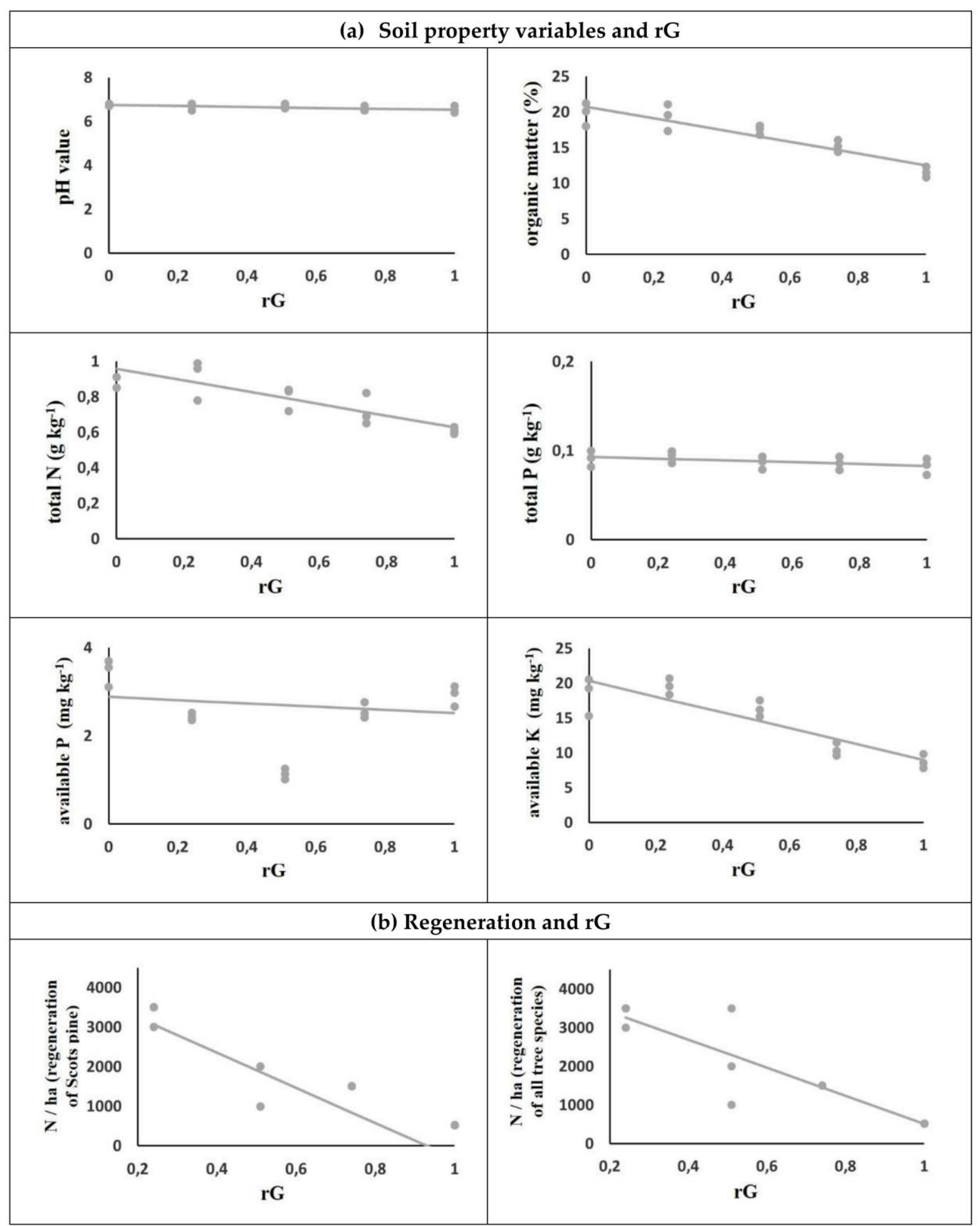

Figure 7. (a) Graphs of the relationships between soil property variables and selective logging intensity (rG; selective logging weight); (b) Graph of the relationship between regeneration (N/ha) and selective logging intensity (rG; selective logging weight).

\section{Discussion}

Our analysis of the harvest event showed that the treatments in our silvicultural experiment differed in selective logging intensity ( $\mathrm{rG}$; selective logging weight), but not in terms of selective logging type (NG). We can therefore concentrate our interpretations on the selective logging intensity 
when removal focuses on an even selection of different size classes. The relatively strong change in D_200 and Dg_200 after logging at MI and HI treatment parcels (Table 2) can be explained by the high reduction in stem numbers and relatively even selection of sizes classes.

\subsection{Soil Compaction, Reduced Soil Moisture and Nutrient Depletion Caused by Selective Logging}

Our study showed that heavy logging in continental, natural Scots pine forest had a significantly adverse impact on soil physical and chemical properties, even after almost two decades.

\subsubsection{Soil Compaction and Decrease of Organic Matter Caused by Logging}

Studies from other regions in the world have shown that ground-based logging can cause serious disturbance to soil physical and chemical properties as a result of soil compaction and nutrient loss $[6-8,66]$. Logging practices that use heavy machinery and high intensity logging have significantly negative effects on soil structural characteristics, aeration, and water balance, which is especially true of sandy soils, which recover very slowly [31,67]. In this study, we showed that although no heavy machines were used for skidding and cleaning during or after the harvesting, high-intensity logging and clear-cutting significantly affected the soil bulk density, total porosity, temperature, and moisture regime (Figures 4 and 5). These findings are similar to those of previous studies by Hajabbasi et al. [66], Hashimoto and Suzuki [68], Ares et al. [11] and Gebauer et al. [1], who reported that the absence of shade or the reduction of shade in intensively logged areas generally increases both the soil temperature and compaction. Zhou et al. [8] reported similar findings for mixed forests in northeastern China, where an increase in harvesting intensity resulted in a decrease in soil organic matter, porosity, and water holding capacity, and an increase in soil bulk density. A decrease of soil organic matter also means depletion of carbon pools. This aspect is relevant for the contribution of these forests for carbon sequestration, and consequently, climate change mitigation. Recently, Mongolia submitted its first contribution in the frame of the UNREDD initiative [18].

However, not all thinning and harvest studies conclude that thinning always has an adverse impact on physical soil properties. Soil organic matter or soil organic carbon, respectively, were not affected [37] or even increased under moderate thinning [69]. Obviously, site conditions (soil, climate etc.) play also an important role.

\subsubsection{Changes Related to Soil Temperature and Moisture Content}

In our comparative study, the most adverse changes in soil temperature and moisture content were found in CC treatment parcel (Figures 4 and 5). Critical low moisture content (below 10 percent) was measured within $40 \mathrm{~cm}$ depth from the soil surface, and moisture content was $15.2 \%, 13.5 \%$, and $13.1 \%$ less than that of soil moisture in RE at depths of $10 \mathrm{~cm}, 25 \mathrm{~cm}$, and $35 \mathrm{~cm}$, respectively. Higher soil temperatures were observed in HI and CC treatments, with the highest mean temperatures occurring in the topsoil $(10 \mathrm{~cm})$. Savin et al. [70] made similar observations in managed larch stands in Mongolia. Hence, in heavy logged forests, soil moisture contents were low as a result of less pore space due to an elevated bulk density levels. We suggest that logging leads to a reduction in soil moisture retention as a result of increased evaporation, which is in turn triggered by direct sun radiation due to the reduction or lack of shading following harvest. This aspect is somewhat interesting, since thinning is currently discussed as one potential option to make forest stands even more resilient against droughts in the region. Several studies recently emphasized that thinning can have positive effects on water availability for the remaining trees, partly due to reduced competition [71-73]. Recently it was also shown that reduction of competitors significantly promotes tree growth of birch and larch in the region [46]. However, these studies focused on the remaining trees, whereas our study puts the focus on long term effects on regeneration.

Wang et al. [74] noted that keeping the soil water balance at relatively high levels over the post-logging period is a prerequisite for regeneration success. Decreased soil water leads to lower survival rates and reduced tree growth and stunts the natural regeneration of woody plants [75]. It 
has recently been shown that survival rate and growth performance of artificially established Scots pine plantations in the region are significantly related to the number of dry days and relative air humidity [76]. Recent studies also showed that the growth response of mature coniferous trees in the region correlates significantly with sufficient precipitation $[16,77,78]$. This highlights the dependency of forests in Northern Mongolia and neighboring regions on sufficient soil moisture content. Reduction of soil moisture, however, also affects the availability of nutrients for plants.

\subsubsection{Impact of Logging on Nutrients and Their Availability for Trees}

Availability of $\mathrm{N}$ and $\mathrm{P}$ limits growth [79]. Drought stress usually has negative impact on $\mathrm{N}$ and $\mathrm{P}$ concentration in plants [80]. Nitrogen $(\mathrm{N})$ is a key nutrient for plant development and growth. Phosphorus $(\mathrm{P})$ is important for different physiological processes, supports the development of the root system, and increases the ability of the plant to tolerate drought stress $[79,81]$. Potassium (K) is an essential nutrient that influences growth, yield, and health of plants [82]. A deficiency in K can increase the susceptibility of plants against drought, frost, and different pathogens [82]. The LMM results (Figure 7a) showed that $\mathrm{pH}$ value, organic matter, total $\mathrm{N}$, and available $\mathrm{K}$ were most significantly negatively affected by logging. $\mathrm{N}, \mathrm{K}$, and $\mathrm{pH}$ value, are among the main indicators that determine site productivity in forestry [83]. In our study, nutrient loss in the soil resulted from intensive logging. There are studies from other relatively dry regions that showed that thinning triggered depletion of nitrogen, phosphorus, and potassium, for example in the Mediterranean forest areas [84]. Saarsalmi et al. [85] found in a logging experiment in a Scots Pine forest in Eastern Finland that on more fertile sites whole tree harvesting (including all residuals) significantly decreased the total amount of $\mathrm{N}$ and of available $\mathrm{P}$ and other nutrients in the organic layer. This is somewhat similar to our results, since all logging residuals were removed on the research plots after the harvest and the time frame after the harvest events was of a similar length. But there are also studies in which thinning had little effects on soil chemical properties [86] or even increased nitrogen. The latter was found, for example, by Cheng et al. [37] in Chinese fir stands in eastern China, which they attributed to increased decomposition after the harvest event.

\subsubsection{Important Consideration for Forest Management in the Region with Regard to Soil}

Another important aspect regarding the impact of logging on soil in Mongolia is that forest stands on permafrost soils will require special attention $[15,30]$. The disjunctive occurrence of permafrost in Mongolia is partly due to exposition and the sunblocking forest cover $[70,87]$. Together, rising temperatures due to climate change and reduced shading due to harvesting are likely to accelerate the melting of permafrost in soils. Just recently, water logging, potentially induced by degradation of permafrost soils, has been identified as one reason for the dieback of larch stands in the Mongolian Khentii Mountains [88]. Allen et al. [89] and Willams et al. [90] also reported that semi-arid forests can experience seasonal water stress and are especially vulnerable to even slight increases of water stress. A phase of increased water stress can lead to the dieback of mature trees, which results in increased soil evaporation and a strong drying of the surrounding environment [88]. This underlines the need to develop forest management protocols that maintain continuous forest cover, which help to protect the soil capacity.

\subsection{Low-Intensity Selective Logging Regimes Can Promote Natural Scots Pine Regeneration}

Our findings demonstrated that low (LI) and medium intensity (MI) logging promotes natural forest regeneration and they conserve capacity of the forest to regenerate with conifer tree species. High intensity logging (HI) and clear-cutting (CC) showed a limited regeneration of Scots pine and created more suitable conditions for broad-leaf tree regeneration and for abundant herb and shrub coverage. In general, reproduction of Scots pine in the study area is relatively low. The highest regeneration densities were found in LI (3333 seedlings ha ${ }^{-1}$ ) and MI (2167 seedlings ha ${ }^{-1}$ ) treatment parcels (Figure 5, Figure 6). These numbers are somewhat comparable to numbers in the Scots pine-birch 
forests along the Bugant River [30] and to numbers reported for the region in the national forest inventory [29]. Therefore, we consider these numbers to be sufficient. The data for the reference treatment (RE) suggest that natural regeneration was largely suppressed due to resource competition (presumably sunlight in particular) with larger trees. Low-intensity selective logging improved the conditions for regeneration by improving light and resource availability for seedlings and potentially also for seedling germination.

\subsection{Implications for Managing Selective Logging and Other Disturbance Impact in Continental Scots Pine Forests}

Scots pine forests growing along the southern border of the Siberian boreal forests are vulnerable to intensive logging and other disturbances, such as fire and pests [91,92]. According to Tikhonova et al. [28], who studied the suitability of soil for different coniferous species across the forest fund of neighboring Tuva, Scots pine could potentially grow in $98 \%$ of the sites. This was the highest value for all examined tree species. The reason that Scots pine is not fully present at all viable sites is most likely related to its different protection capacities (e.g. bark) and response to common disturbance regimes, such as fire, and intensive logging of Scots pine [28]. Wildfires are also reported to reduce soil water retention capacity in Mongolia [26,93], which is similar to our above mentioned results about intensive logging. This may consequently affect the tree species composition. Intensive fires that trigger tree mortality may promote dominance of other tree species that are able to recover more quickly. However, pine may be better protected against low-intensity fires, which just reduce vitality and growth across the stand, than thin-barked aspen or birch trees [78], but less protected than larch [28]. Thus, the relationship between fire intensity and its effects on species composition is somewhat similar to what we found with regard to the effects of logging intensity, although the mechanisms are different. High-intensity logging leads to the regeneration of deciduous tree species, whereas selective logging under low and medium intensities ensures a successful natural regeneration or recovery of Scots pine trees. More intensive logging results in conditions that are more suitable for the regeneration of pioneering deciduous tree species and the rapid development of herbal and shrub coverage, which can be caused by increased sun radiation due to reduced shading [94,95]. Dense herbal coverage often creates conditions that handicap the germination of trees [96], consequently weakening the regeneration capacity of the forest. Increased replacement of Scots pine forests by deciduous forests after intensive large-scale disturbances, such as clear cuts and forest fires, was recently reported in other studies in the West Khentii $[17,19,30,97]$. Thus, in addition to climate and soil, the disturbance regime and competition are key factors determining the composition and structure of forests in the mountain forest steppe. Improved control of the different disturbance regimes would therefore be an appropriate management instrument for sustaining or even increasing forest cover throughout the region [30].

We have showed that the continental pine forest ecosystems are especially vulnerable to logging intensity. However, it has also been observed that in less continental regions, e.g. in the Baltics [36], post-logging regeneration density and stand structure in pine forests are a consequence of logging intensity. Zhou et al. [8] emphasized the importance of appropriate logging intensity to be applied in silvicultural practice and taking into account the climatic features of the region. In addition to optimizing productivity, the maintenance of soil properties and natural regeneration are main objectives in sustainable forestry [36,98-100]. High-intensity logging appears to create soil conditions that hamper pine seed germination and/or seedling growth. The absence of Scots pine seedlings and the predominance of deciduous tree seedlings in areas subjected to high-intensity logging or clear-cutting suggests an existing risk of replacement of coniferous forests with deciduous trees or even deforestation. The replacement of coniferous trees by deciduous trees represent one aspect of wide-spread creeping forest degradation in the utilized forest regions of the Mongolian mountain forest steppe. Consequently, the observed impacts of selective logging intensity on natural regeneration and overall soil properties suggest that high-intensity logging and clear-cutting in this region should be 
avoided. Instead, appropriate low-intensity selective logging regimes should be implemented in order to maintain the sustainability of these forest ecosystems.

\section{Conclusions}

Harvest practices need to be adapted to the specific regional conditions and should not be transferred from one region to another without researching their consequences on the local forest functions. The ultracontinental climate and special conditions in the forest-steppe zone necessitate management practices that are tailored to this region. Maintenance of soil properties and promotion of regeneration are of utmost importance. Our study indicates that low intensity selective logging provides the most suitable solution for maintaining appropriate forest regeneration while allowing for timber harvesting. In the RE parcel, we assume that the relatively high density of trees and the shading effect of mature trees limits regeneration. In the HI and CC parcels, regeneration is likely limited by reduced soil fertility and soil moisture, and, to some extent, competition with a denser herbaceous layer. However, soil capacity was highest without any logging activities at all and decreased linearly with increasing harvest intensity. Our finding that organic matter significantly decreases with increasing selective logging intensity may have also implications for the evaluation and projection of carbon sequestration capacities of these forests in the frame of climate change mitigation initiatives.

Our observations nearly two decades after the logging event indicate that intense logging seriously challenged the ecosystem's resilience. Intense harvesting, combined with other disturbance effects and climate change, may lead to long-term unstable conditions or even forest breakdown and replacement by non-forest ecosystems. Given the increasing demand for wood, we suggest that low-intensity selective logging may be the best option for meeting demand while also protecting forest cover, counteracting forest and land degradation, and ensuring the long-term health of the forest ecosystem. We recommend developing specific silvicultural practices with low intensity and selective logging regimes, as well as developing forest management policies that prioritize the maintenance of continuous forest cover in the region.

Author Contributions: SG was responsible for funding acquisition and project administration. NB was responsible for the research design and conceptualization of the study. GB, PB, TB and MK collected and processed the field data. MK, SG and AG analyzed the data. SG and NB wrote the draft. AG revised the draft.

Funding: This research was supported by the Asia Research Center (ARC) at the National University of Mongolia and the Korea Foundation of Advanced Studies in Ulaanbaatar.

Acknowledgments: We acknowledge the Tujyin Nars National Park Administration and the Forest and Wildlife Centre of Selenge province for their collaboration and support conducting field measurements and data collection. We are thankful to Erin Gleeson and Irina Karpova for the language editing of our manuscript. We thank two anonymous reviewers for valuable comments on our manuscript.

Conflicts of Interest: The authors declare no conflict of interest.

\section{References}

1. Gebauer, R.; Neruda, J.; Ulrich, R.; Martinkova, M. Soil Compaction-Impact of Harvesters' and Forwarders' Passages on Plant Growth. In Sustainable Forest Management-Current Research; Diez, J., Ed.; InTech Europe: Rijeka, Croatia, 2012; pp. 179-196.

2. Bulmer, C.E.; Simpson, D.G. Soil compaction and water content as factors affecting the growth of lodgepole pine seedlings on sandy clay loam soil. Can. J. Soil. Sci. 2005, 85, 667-679.

3. Gomez, A.; Powers, R.F.; Singerz, M.J.; Horwath, W.R. Soil compaction effects on growth of young ponderosa pine following litter removal in California's Sierra Nevada. Soil Sci. Soc. Am. J. 2002, 66, 1334-1343. [CrossRef]

4. Sanchez, F.G.; Scott, D.A.; Ludovici, K.H. Negligible effects of severe organic matter removal and soil compaction on loblolly pine growth over 10 years. For. Ecol. Manag. 2006, 27, 145-154. [CrossRef]

5. Tan, X.; Curran, M.; Chang, S.; Maynard, D. Early growth responses of lodgepole pine and douglas-fir to soil compaction, organic matter removal, and rehabilitation treatments in southeastern British Columbia. For. Sci. 2009, 55, 210-220. 
6. Missanjo, E.; Kamanga-Thole, G. Impact of Site Disturbances from Harvesting and Logging on Soil Physical Properties and Pinus kesiya Tree Growth. Int. Sch. Res. Not. 2014, 2014, 1-7. [CrossRef] [PubMed]

7. Hosseini, S.A.; Akbarimehr, M.; Emadian, S.F.; Agh, A. Considering the soil compaction status on logging areas in a Hyrcanian forest. J. For. Sci. 2016, 61, 210-215.

8. Zhou, X.; Zhou, Y.; Zhou, C.; Wu, Z.; Zheng, L.; Hu, X.; Chen, H.; Gan, J. Effects of Cutting Intensity on Soil Physical and Chemical Properties in a Mixed Natural Forest in Southeastern China. Forests 2015, 6, 4495-4509. [CrossRef]

9. Blanco, J.A.; Imbert, J.B.; Castillo, F.J. Influence of site characteristics and thinning intensity on litterfall production in two Pinus sylvestris L. forests in the Western Pyrenees. For. Ecol. Manag. 2006, 237, 342-352. [CrossRef]

10. Lafleur, B.; Fenton, N.J.; Pare, D.; Simard, M.; Bergeron, Y. Contrasting Effects of Season and Method of Harvest on Soil properties and the growth of Black Spruce regeneration in the Boreal Forested Peatlands of Eastern Canada. Silva Fenn. 2010, 44, 799-813. [CrossRef]

11. Ares, A.; Terry, T.A.; Miller, R.E.; Anderson, H.W.; Flaming, B.L. Ground-based forest harvesting effect on soil physical properties and Douglas-fir growth. Soil Sci. Soc. Am. J. 2005, 69, 1822-1832. [CrossRef]

12. IPCC. Summary for Policymakers. In Climate Change 2013: The Physical Science Basis. Contribution of Working Group I to the Fifth Assessment Report of the Intergovernmental Panel on Climate Change; Stocker, T.F., Qin, D., Plattner, G.-K., Tignor, M., Allen, S.K., Boschung, J., Nauels, A., Xia, Y., Bex, V., Midgley, P.M., Eds.; Cambridge University Press: Cambridge, United Kingdom and New York, NY, USA, 2017; Available online: http://www.ipcc.ch/pdf/assessmentreport/ar5/wg1/WG1AR5_SPM_FINAL (accessed on 22 June 2017).

13. Batima, P.; Natsagdorj, L.; Gombluudev, P.; Erdenetsetseg, B. Observed climate change in Mongolia. AIACC Working Paper 13. 2005, p. 26. Available online: http://www.start.org/Projects/AIACC_Project/working_ papers/Working\%20Papers/AIACC_WP_No013.

14. Dulamsuren, C.; Hauk, M. Spatial and seasonal variation of climate on steppe slopes of the northern Mongolian mountain taiga. Grassl Sci 2008, 54, 217-230. [CrossRef]

15. Bohannon, J. The big thaw reaches Mongolia's pristine north. Science 2018, 319, 567-568. [CrossRef] [PubMed]

16. Dulamsuren, C.; Hauck, M.; Khishigjargal, M.; Leuschner, H.H.; Leuschner, C. Diverging climate trends in Mongolian taiga forests influence growth and regeneration of Larix sibirica. Oecologia 2010, 163, 1091-1102. [CrossRef]

17. Tsogtbaatar, J. Deforestation and Reforestation of Degraded Forestland in Mongolia. In The Mongolian Ecosystem Network-Ecological Research Monographs; Yamamura, N., Fujita, N., Maekawa, A., Eds.; Springer: Tokyo, Japan, 2012; pp. 83-99.

18. Government of Mongolia. Mongolia's Forest Reference Level submission to the United Nations Framework Convention on Climate Change; UN-REDD Mongolia National Programme; Ministry of Environment and Tourism: Ulaanbaatar, Mongolia, 2018.

19. Mühlenberg, M.; Appelfelder, J.; Hoffmann, H.; Ayush, E.; Wilson, K.J. Structure of the montane taiga forests of West Khentii, Northern Mongolia. J. For. Sci. 2012, 58, 45-56. [CrossRef]

20. Corsi, A.; Dore, G.; Nagpal, T.; Whitten, T.; Iyer, R.; Mearns, R.; Lyngdoh, Y.R.; Rivera, S. Mongolia environment monitor: Mongolia Environment Monitor (Mongolian) 2002; Report Number: 25836; World Bank: Washington, DC, USA, 2002; p. 55. Available online: http:/ / documents.worldbank.org/curated/en/600981468323101125/ Mongolia-Environment-Monitor-2002(Mongolian version).

21. Ykhanbai, H. Mongolian Forestry Outlook Study; Asia-Pacific Forestry Sector Outlook Study II; Working Paper Series; FAO: Bangkok, Thailand, 2010; p. 49. Available online: http:/ / www.fao.org/3/a-am616e.pdf.

22. FAO. State of the world's forest 2011; Food and Agriculture Organization: Rome, Italy, 2011; p. 164.

23. Teusan, S. Analyse der Waldentwicklung in der nördlichen Mongolei seit dem politischen Umbruch im Jahr 1991 unter besonderer Berücksichtigung feuerökologischer. Aspekte. Dissertation (Ph.D. Thesis), Freie Universität, Berlin, Germany, 2018; p. 171. (In German)

24. Minderlein, S.; Menzel, L. Evapotranspiration and energy balance dynamics of a semi-arid mountainous steppe and shrubland site in northern Mongolia. Environ. Earth Sci 2015, 73, 593-609. [CrossRef]

25. Karthe, D.; Heldt, S.; Houdret, A.; Borchardt, D. IWRM in a country under rapid transition: lessons learnt from the Kharaa river basin, Mongolia. Environ. Earth Sci. 2015, 73, 681-695. [CrossRef]

26. Kasimov, N.; Karthe, D.; Chalov, S. Environmental change in the Selenga River-Lake Baikal Basin. Reg. Einviron. Chang. 2017, 17, 1945-1949. [CrossRef] 
27. Dulamsuren, C.; Hauck, M.; Mühlenberg, M. Ground vegetation in the Mongolian taiga forest-steppe ecotone does not offer evidence for the human origin of grasslands. Appl. Veg. Sci. 2005, 8, 149-154. [CrossRef]

28. Tikhonova, I.V.; Mukhortova, L.V.; Danilova, I.V.; Mikhailova, I.A. Ocenka lesorastitelnogo potenciala pochv respubliki Tyva dlya osnovnyh lesoobrazujushih vidov hvojnyh. (Assessment of Soil Suitability for Growth of Coniferous Forests Species in Tuva Republic). Lesovedenie 2018, 3, 194-209. (In Russian)

29. MET: Ministry of Environment and Tourism of Mongolia Mongolian. Multipurpose National Forest Inventory 2014-2016, 1st ed.; MET: Ulaanbaatar, Mongolia, 2016; p. 126.

30. Gradel, A. Reaktion von Waldbeständen am Rande der südlichen Taiga auf Klimafaktoren, natürliche und waldbauliche Störungen/Response of forest stands at the edge of the southern taiga to climate factors, natural and silvicultural disturbances. Ph.D. Thesis, Georg-August-Universität, Göttingen, Germany, 2017; p. 191.

31. Eroğlu, H.; Sariyildiz, T.; Kucuk, M.; Sancal, E. The effects of Different Logging Techniques on the Physical and Chemical Characteristics of Forest Soil. Baltic For. 2016, 22, 139-147.

32. Behjou, F.K.; Mollabashi, O.G. Impact of logging intensity on stem density, basal area and biodiversity indices five years after logging in a Caspian hardwood forest. J. For. Sci. 2017, 63, 167-172.

33. JICA. The forest resources management study in Selenge province; Final report; JICA, 1998; p. 116.

34. Peel, M.C.; Finlayson, B.L.; McMahon, T.A. Updated world map of the Köppen-Geiger climate classification, Hydrol. Earth Syst. Sci. 2007, 11, 1633-1644. [CrossRef]

35. Regzedmaa, M. Climate Resources and Changes of Meteorological Data of Selenge Province; Sukhbaatar, Mongolia, 2008; pp. 11-25. (In Mongolian)

36. Brumelis, G.; Strazds, M.; Eglava, Ž. Stand Structure and Spatial Pattern of Regeneration of Pinus sylvestris in a Natural Treed Mire in Latvia. Silva Fennica 2009, 43, 767-781. Available online: http:/ / www.metla.fi/ silvafennica/full/sf43/sf435767.pdf. [CrossRef]

37. Cheng, X.; Yu, M.; Wang, G.G. Effects of Thinning on Soil Organic Carbon Fractions and Soil Properties in Cunninghamia lanceolata Stands in Eastern China. Forests 2017, 8, 198. [CrossRef]

38. Edaphic Scientific 2018. Available online: https://www.edaphic.com.au/soil-water-compendium/soilmoisture-sensor-calibration/ (accessed on 04 September 2018).

39. Walkley, A.; Black, I.A. An examination of the Degtjareff method for determining organic carbon in soils: Effect of variations in digestion conditions and of inorganic soil constituents. Soil Sci. 1934, 63, 251-263. [CrossRef]

40. Kjeldahl, J. New Method for the Determination of Nitrogen. Chem. News 1883, 48, 101-102. [CrossRef]

41. Olsen, S.R.; Cole, C.V.; Watanabe, F.S.; Dean, L.A. Estimation of available phosphorus by extraction with sodium bicarbonate; Government Printing Office: Washington, D.C., USA, 1954; p. Circ. 939.

42. Bray, R.H.; Kurtz, L.T. Determination of total, organic, and available forms of phosphorus in soils. Soil Sci. 1945, 59, 39-45. [CrossRef]

43. Hosseinpur, A.R.; Samavati, M. Evaluation of chemical extractants for the determination of available potassium. Commun. Soil Sci. Plant Anal. 2008, 39, 1559-1570. [CrossRef]

44. Dorjsuren, C.; Dugarjav, C.; Tsogt, Z.; Tsedendash, G.; Chuluunbaatar, T. References for the Mongolian Forest Mensuration; Bembi san: Ulaanbaatar, Mongolia, 2012; p. 263. (In Mongolian)

45. Von Gadow, K.; Zhang, Y.C.; Wehenkel, C.; Pommerening, A.; Corral-Rivas, J.; Korol, M.; Myklush, S.; Hui, G.Y.; Kiviste, A.; Zhao, X.H. Forest Structure and Diversity. In Continuous Cover Forestry; Pukkala, T., von Gadow, K., Eds.; Springer Netherlands: Dordrecht, The Netherlands, 2012; pp. 29-83.

46. Gradel, A.; Ammer, C.; Batsaikhan, G.; Ochirragchaa, N.; Batdorj, D.; Wagner, S. On the effect of thinning on tree growth and stand structure of white birch (Betula platyphylla Sukaczev) and Siberian larch (Larix sibirica Ledeb.) in Mongolia. Forests 2017, 8, 105. [CrossRef]

47. Murray, D.M.; von Gadow, K. A flexible yield model for regional timber forecasting. South J. Appl. For. 1993, $17,112-115$.

48. Vítková, L.; Ni Dhubhain, A.; Pommerening, A. Agreement in Tree Marking: What Is the Uncertainty of Human Tree Selection in Selective Forest Management? For. Sci. 2016, 62, 288-296. [CrossRef]

49. Von Gadow, K.; Hui, G.Y. Characterizing forest spatial structure and diversity. In Sustainable Forestry in Temperate Regions; Björk, L., Ed.; SUFOR, University of Lund: Lund, Sweden, 2002; pp. 20-30. 
50. Fisher, R.A. Statistical Methods for Research Workers. Biological Monographs and Manuals V. Oliver and Boyd Ltd.: (Edinburgh), Great Britain, 1934, 5th ed. p. 319. Available online: http:/ /www.haghish.com/resources / materials/Statistical_Methods_for_Research_Workers.pdf (accessed on 09 November 2018).

51. O'Brien, R.G. A General ANOVA Method for Robust Tests of Additive Models for Variances. J. Am. Stat. Association 1979, 74, 877-880. [CrossRef]

52. McDonald, J.H. Handbook of Biological Sciences; Sparky House Publishing: Baltimore, Maryland, 2014, 3rd ed. pp. 157-164. Available online: http://www.biostathandbook.com/kruskalwallis.html (accessed on 10 December 2018).

53. STHDA Statistical tools for high-throughout data analysis. 2018. Available online: http:/ /www.sthda.com/ english/wiki/one-way-anova-test-in-r\#assumptions-of-anova-test (accessed on 22 January 2019).

54. R Development Core Team. R: A Language and Environment for Statistical Computing, R Version 3.5.1; R Foundation for Statistical Computing: Vienna, Austria, 2018. The R Project for Statistical Computing. Available online: http:/ / www.R-project.org (accessed on August 05 2018).

55. Hadley, W.; Romain, F.; Lionel, H.; Müller, K. A Grammar of Data Manipulation. R package version 0.7.8. 2018. Available online: https:/ /CRAN.R-project.org/package=dplyrg (accessed on January 22 2019).

56. Kassambara, A. ggpubr: 'ggplot2' Based Publication Ready Plots. R package version 0.2. 2018. Available online: https: / CRAN.R-project.org/package=ggpubr (accessed on January 22 2019).

57. Fox, J.; Weisberg, S. An R Companion to Applied Regression; Sage: Thousand Oaks, CA, USA, 2nd ed. Available online: http:/ / socserv.socsci.mcmaster.ca/jfox/Books/Companion (accessed on 11 December 2017).

58. Edwards, A.L. The Correlation Coefficient. In An introduction to Linear regression and Correlation; W. H. Freeman: San Francisco, CA, USA, 1976; pp. 33-46.

59. Crawley, M.J. The R-Book; Wiley: New York, NY, USA, 2007; p. 942.

60. Zuur, A.F.; Ieno, E.N.; Walker, N.J.; Saveliev, A.A.; Smith, G.M. Mixed EffectsModels and Extensions in Ecology with R; Springer: New York, NY, USA, 2009; p. 574.

61. R-bloggers: Linear mixed models in R. Post by Luis. 2011. Available online: https:/ /www.r-bloggers.com/ linear-mixed-models-in-r/ (accessed on 24 September 2017).

62. Robinson, A.P.; Hamann, J.D. Forest Analytics with R-An Introduction; Springer: New York, NY, USA, 2011; p. 354 .

63. Grothendieck, G. nls2: Non-Linear Regression with Brute Force. R Package Version 0.2. Available online: http:/ /CRAN.R-project.org/package=nls2 (accessed on 19 January 2017).

64. Pinheiro, J.; Bates, D.; DebRoy, S.; Sarkar, D.; R Development Core Team. nlme: Linear and Nonlinear Mixed Effects Models. R Package Version 3.1-113. Available online: http:/ / packages.renjin.org/package/org.renjin. cran/nlme/3.1-113 (accessed on 21 January 2017).

65. Sarkar, D. Lattice: Multivariate Data Visualization with R; Springer: New York, NY, USA, 2008; p. 268.

66. Hajabbasi, M.A.; Jalalian, A.; Karimzadeh, H.R. Deforestation effects on soil physical and chemical properties, Lordegan, Iran. Plant and Soil 1997, 190, 301-308. [CrossRef]

67. Ampoorter, E.; Goris, R.; Cornelis, W.M.; Verheyen, K. Impact of mechanized logging on compaction status of sandy forest soils. For. Ecol. Manag. 2007, 241, 162-174. [CrossRef]

68. Hashimoto, S.; Suzuki, M. The impact of clear-cutting on soil temperature: A comparison between and after clear-cut and control sites. J. For. Res. 2004, 9, 125-132. [CrossRef]

69. Ma, J.; Kang, F.; Cheng, X.; Han, H. Moderate thinning increases soil organic carbon in Larix principes-rupprechtii (Pinaceae) plantations. Geoderma 2018, 329, 118-128. [CrossRef]

70. Savin, E.N.; Milyutin, L.I.; Krasnoshhekov, J.N.; Korotkov, I.A.; Suncov, A.V.; Dugarzhav, C.; Cogoo, Z.; Dorzhsuren, C.; Zhamjansurjen, S.; Gombosuren, N. Forests of the Mongolian People's Republic (Larch forests of the Eastern Khentey), Soviet-Mongolian Expedition; Nauka, Siberian Department: Novosibirsk, Russia, 1988; p. 176. (In Russian)

71. Gebhardt, T.; Häberle, K.H.; Matyssek, R.; Ammer, C. The more, the better? Water relations of Norway spruce stands after progressive thinning. Agric. For. Meteorol. 2014, 197, 235-243. [CrossRef]

72. Olivar, J.; Bogino, S.; Rathgeber, C.; Bonnesoeur, V.; Bravo, F. Thinning has a positive effect on growth dynamics and growth-climate relationships in Aleppo pine (Pinus halepensis L.) trees of different crown classes. Ann. For. Sci. 2014, 71, 395-404.

73. Del Rio, M.; Bravo-Oviedo, A.; Pretzsch, H.; Löf, M.; Ruiz-Peinado, R. A review of thinning effects on Scots pine stands: From growth and yield to new challenges under global change. For. Syst. 2017, 26, eR03S. 
74. Wang, Y.; Bonell, M.; Feger, K.-H.; Yu, P.; Xiong, W.; Xu, L. Changing Forestry Policy by Integrating Water Aspects into Forest/Vegetation Restoration in Dryland Areas in China. Agric. Water Ecol. 2012, 26, $59-67$.

75. Hou, Q.S.; Han, X.L.; Han, S.F. A primary study on the soil drying in the forest and grassland in the Loess Plateau. Soil and Water Conserv. in China 1999, 5, 11-14.

76. Gerelbaatar, S.; Batsaikhan, G.; Tsogtbaatar, J.; Battulga, P.; Baatarbileg, N.; Gradel, A. Early survival and growth of planted Scots pine (Pinus sylvestris L.) seedlings in northern Mongolia. In Book of Abstracts - GMIT Symposium on Environmental Science and Engineering; Vossen, P., Karthe, D., Gunsmaa, B., Enkhjargal, S., Eds.; Nalaikh, Mongolia, 2018; pp. 8-9. Available online: http://gmit.edu.mn/site/files/downloads/gmit_sese2018_book-of-abstracts.pdf.

77. Demina, A.V.; Belokopytova, L.V.; Andreev, S.G.; Kostyakova, T.V. Babushkina, E.A. Radial increments dynamics of Scots Pine (Pinus sylvestris L.) as an indicator of hydrothermal regime of the Western Transbaikalia forest steppe. Contemp. Probl. Ecol. 2017, 10, 476-487. [CrossRef]

78. Gradel, A.; Batsaikhan, G.; Ochirragchaa, N.; Batdorj, D.; Kusbach, A. Climate-growth relationships and pointer year analysis of a Siberian larch (Larix sibirica Ledeb.) chronology in the Mongolian mountain forest steppe compared to white birch (Betula platyphylla Sukazcev). For. Ecosyst. 2017, 4, 22. [CrossRef]

79. Razaq, M.; Zhang, P.; Shen, H.L. Influence of nitrogen and phosphorous on the growth and root morphology of Acer mono. PloS one 2017, 12, 0171321. [CrossRef] [PubMed]

80. He, M.; Dijkstra, F.A. Drought effect on plant nitrogen and phosphorus: a meta-analysis. New Phytologist 2014, 204, 924-931. [CrossRef] [PubMed]

81. Faustino, L.I.; Bulfe, N.M.; Pinazo, M.A.; Monteoliva, S.E.; Graciano, C. Dry weight partitioning and hydraulic traits in young Pinus taeda trees fertilized with nitrogen and phosphorus in a subtropical area. Tree physiology 2013, 33, 241-251. [CrossRef] [PubMed]

82. Wang, M.; Zheng, Q.; Shen, Q.; Guo, S. The critical role of potassium in plant stress response. Int. J. Mol. Sci. 2013, 14, 7370-7390. [CrossRef] [PubMed]

83. Wall, A. Risk analysis of effects of whole-tree harvesting on site productivity. For. Ecol. Manag. 2012, 282, 175-184. [CrossRef]

84. Baena, C.W.; Andrés-Abellán, M.; Lucas-Borja, M.E.; Martínez-García, E.; García-Morote, F.A.; Rubio, E.; López-Serrano, F.R. Thinning and recovery effects on soil properties in two sites of a Mediterranean forest, in Cuenca Mountain (South-eastern of Spain). For. Ecol. Manag. 2013, 308, 223-230. [CrossRef]

85. Saarsalmi, A.; Tamminen, P.; Kukkola, M.; Hautajärvi, R. Whole-tree harvesting at clear-felling: Impact on soil chemistry, needle nutrient concentrations and growth of Scots pine. Scandinavian J. For. Res. 2010, 25, 148-156. [CrossRef]

86. Jang, W.; Page-Dumroese, D.S.; Keyes, C.R. Long-term soil changes from forest harvesting and residue management in the northern rocky mountains. Soil Sci. Soc. Am. J. 2016, 80, 727-741. [CrossRef]

87. Kopp, B.J.; Minderlein, S.; Menzel, L. Soil moisture dynamics in a mountainous headwater area in the discontinuous permafrost zone of northern Mongolia. Arct. Alp. Res. 2014, 46, 459-470. [CrossRef]

88. Juřička, D.; Novotná, J.; Houška, J.; Pařílková, J.; Hladký, J.; Pecina, V.; Cihlářová, H.; Burnog, M.; Elbl, J.; Rosická, Z.; Brtnický, M.; Kynický, J. Large-scale permafrost degradation as a primary factor in Larix sibirica forest dieback in the Khentii massif, northern Mongolia. J. For. Res. 2018, 29, 1-12. [CrossRef]

89. Allen, C.D.; Macalady, A.K.; Chenchouni, H.; Bachelet, D.; Mcdowell, N.; Vennetier, M.; Kitzberger, T.; Rigling, A.; Breshears, D.D.; Hogg, E.N. A global overview of drought and heat-induced tree mortality reveals emerging climate change risks for forests. For. Ecol. Manag. 2010, 259, 660-684. [CrossRef]

90. Willams, A.P.; Allen, C.D.; Macalady, A.K.; Griffin, D.; Woodhouse, C.A.; Meko, D.M.; Swetnam, T.W.; Rauscher, S.A.; Seager, R.; Grissino-Mayer, H.D.; Dean, J.S.; Cook, E.R.; Gandodagamage, C.; Cai, M.; McDowell, N.G. Temperature as a potent driver of regional forest drought stress and tree mortality. Nature Climate Change 2013, 3, 292-297. [CrossRef]

91. Kondrashov, L.; Teusan, S.; Chuluunbaatar, T.; Nyamjav, B.; Enkhtur, D.; Goldammer, J. Wildland fire disaster risk assessment for Mongolia; GTZ: Ulaanbaatar, Mongolia; Global Forest Monitoring Center: Pacific Forest Forum, 2008; p. 80.

92. Dulamsuren, C.; Hauck, M.; Leuschner, H.H.; Leuschner, C. Climate response of tree ring width in Larix sibirica growing in the drought-stressed forest-steppe ecotone of northern Mongolia. Ann. For. Sci. 2011, 68, 275-282. [CrossRef] 
93. Kopp, B.; Lange, J.; Menzel, L. Effects of wildfire on runoff generating processes in northern Mongolia. Reg. Environ. Chang. 2016, 17, 1951-1963. [CrossRef]

94. Hanson, J.J.; Stuart, J.D. Vegetation responses to natural and salvage logged fire edges in Douglas-fir/hardwood forests. For. Ecol. Manag. 2005, 214, 266-275. [CrossRef]

95. Shatford, J.P.A.; Hibbs, D.E.; Puettmann, K.J. Conifer Regeneration after Forest Fire in the Klamath-Siskiyous: How Much, How Soon? J. For. 2007, 105, 139-146.

96. Altenkirch, W.; Majunke, C.; Ohnesorge, B. Waldschutz auf ökologischer Grundlage; Verlag Eugen Ulmer: Stuttgart, Germany, 2002; p. 434. (In German)

97. Tsogtbaatar, J. Deforestation and Reforestation need in Mongolia. For. Ecol. Manag. 2004, 201, 57-63. [CrossRef]

98. Kuehne, C.; Puettmann, K.J. Natural Regeneration in Thinned Douglas-fir Stands in Western Oregon. J. Sus. For. 2008, 27, 246-274. [CrossRef]

99. Liira, J.; Sepp, T.; Kohv, K. The ecology of tree regeneration in mature and old forests: combined knowledge for sustainable forest management. J. For. Res. 2011, 16, 184-193. [CrossRef]

100. Brang, P.; Spathelf, P.; Larsen, J.B.; Bauhus, L.; Bonccina, A.; Chauvin, C.; Drossler, L.; Güemes, C.G.; Heiry, C.; Kerr, G.; Lexer, M.J.; Mason, B.; Mohren, F.; Muhlethaler, U.; Nocentini, S.; Svoboda, M. Suitability of close-to-nature silviculture for adopting temperate European forests to climate change. Forestry 2014, 87, 492-503. [CrossRef]

(C) 2019 by the authors. Licensee MDPI, Basel, Switzerland. This article is an open access article distributed under the terms and conditions of the Creative Commons Attribution (CC BY) license (http:/ / creativecommons.org/licenses/by/4.0/). 